\title{
SWOT analysis of floating solar plants
}

\begin{abstract}
Floating photovoltaic (FPV) systems are an emerging technology suitable for energy generation in water bodies. Especially since floating photovoltaic system has its facility floating on water surface, it is extremely important to review the present status and future needs for techno innovations for solar power generation with value-added applications. The paper focuses on SWOT i.e. strengths, weaknesses, opportunities and threats areas for economic growth and increased use of floating solar technology.
\end{abstract}

Keywords: floating PV system, on-site survey, resources survey of photovoltaic, tracking-type floating PV
Volume 3 Issue I - 2019

\author{
Sudhakar $\mathrm{K}^{1,2}$ \\ 'Energy Centre, Maulana Azad National Institute of Technology \\ Bhopal, India \\ ${ }^{2}$ Faculty of Mechanical Engineering, Universiti Malaysia Pahang, \\ Malaysia
}

Correspondence: Sudhakar K, Energy Centre, Maulana Azad National Institute of Technology Bhopal, India, Emailsudhakar@ump.edu.my

Received: December 23, 2018 | Published: February 27, 2019

\section{Introduction}

Solar PV modules: flat and rigid PV modules (mainly Si crystalline made) $)^{1-5}$ or thin-film flexible $\mathrm{PV}^{5-10}$ are widely reported in the literature for power generation. A critical issue in using land-based PV systems is related to the dust, temperature, shadow and performance variability due to limited control of operating conditions.Recent application of Solar includes Solar PV tree, Airport infrastructure, BIPV, BIPVT, CSP Technology ${ }^{11-15}$ Performance analysis of the solar PV Systems,${ }^{10}$ based on energy and exergy analysis is used to assess the technical and economic viability. ${ }^{16-20}$ The recent explosive growth of massive solar plants in some of the world's most remote deserts has stolen some of the spotlights from smaller solar installations that float on water. ${ }^{21-25}$

The impetus for developing floating solar PV over land-based plants stems from increasing prices for undeveloped land with good solar potential, in some cases undermining the economic viability of solar projects. In contrast, water-based plants would not face the same pressure because of much lower competition for potential sites. Floating solar PV is fast emerging as an alternative to conventional ground mounted photo-voltaic systems which are land intensive. It has various benefits like conserving water through the reduction of evaporation, increased generation due to a cooling effect on the panels and requires lesser installation time than conventional land mounted ones. Floating solar PV has drawn interest in recent years because of the potential synergies, with some developers claiming such systems could be as much as $50 \%$ more efficient than land-based solar. The technology is also simpler and offers greater yield than landedbased solar PV. The panels are mounted on floating platforms and are more resistant to overheating that can reduce solar PV output. The technology can be deployed for about $15 \%$ less per megawatt than comparable land-based systems. Floating solar can actually help preserve them by reducing evaporation during hot days in the summer. The environmental impact would likely be minimized by using the reservoirs and waste treatment ponds, though the long-term maintenance requirements and durability of floating solar PV are yet to be seen, initial results are promising: the system can withstand typhoons without significant damage. These could be installed on saline water environments too. Installation potential of such type of systems is huge because of abundant availability of water bodies and lack of enough land.

To analyze the SWOT for a floatovoltaic system this paper will first present the concept of float voltaic. Secondly, analysis of various strength, opportunities, weakness and threats of Floating PV will be presented and conclusions will be drawn.

\section{Basics and Overview of Floating Solar Power plants}

Floating Solar Power is an innovative concept in energy technology to meet the needs of our time. The floating PV system is a new method of solar-energy generation utilizing water surface available on dams, reservoirs, and other bodies of water resulting from the combination of PV technology and floating technology (Figure 1). The floating PV plant consists of a floating system, mooring system, PV system and underwater cables. ${ }^{26-28}$

1. Floating System: A floating body (Structure + Floater) that allows installation of PV module.

2. Mooring System: This allows adjusting water level fluctuations while maintaining its position in a southward direction.

3. PV System: PV Generation equipment, similar to electric junction boxes, which are installed on top of the floating system.

4. Underwater Cable: To transfer generated power from water bodies to the substation.

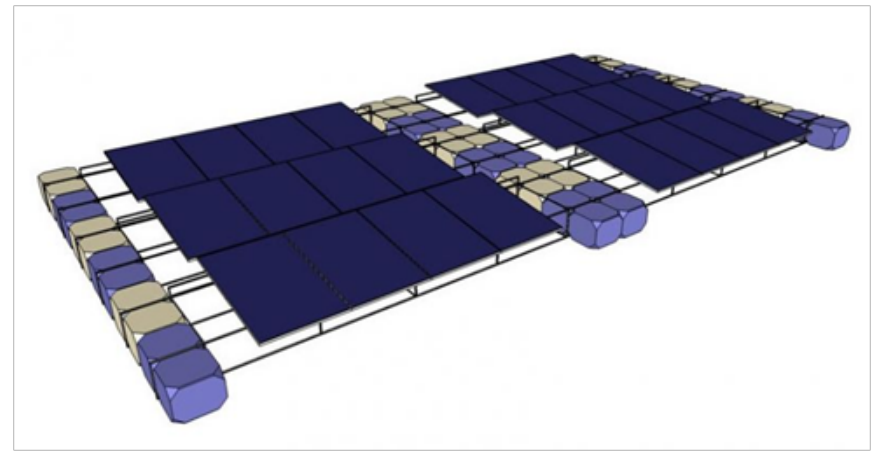

Figure I Floating solar installation.

\section{SWOT analysis}

SWOT Analysis is the most renowned tool for analysis of the overall business and its environment. SWOT is an acronym for Strengths, Weaknesses, Opportunities and Threats. Strengths (S) and Weaknesses (W) are considered to be internal factors over some measure of control exist. Opportunities (O) and Threats $(\mathrm{T})$ are considered to be external factors over which essentially no control exists. SWOT Analysis is a useful technique for understanding the Strengths and Weaknesses, and for identifying both the Opportunities open and the Threats faced. SWOT analysis is the foundation for evaluating the probable opportunities and threats from the external environment and the internal potential and the changing trends. It views all positive and negative factors inside and outside the project 
that affect the success. It helps in the decision-making process and helps in forecasting/predicting the success of the project. The strength, weakness, opportunities and threats of Floating solar plants are highlighted in the following section.

\section{Strength (internal, positive factors)}

1. Floating solar power generating systems typically generate more electricity than ground-mount and rooftop systems due to the cooling effect of the water. ${ }^{28}$

2. The floating platforms are designed and engineered to withstand extreme physical stress, including typhoon and storm conditions.

3. LSA installations reduce water evaporation and algae growth by shading the water.

4. Geographically any water bodies with abundant sunlight can be used to install floating plants.

5. Floating platforms are $100 \%$ recyclable, utilizing high- density polyethylene, which can withstand ultraviolet rays and resists corrosion.

6. More module install compares with the other system.

7. Non-use (and disturbance) of land which conserves the local environment.

8. Easy to erect and faster deployment.

\section{Opportunities (external, positive factors)}

1. Growing innovations in Floating technology

2. Increasing concerns about land neutral energy generation and energy independence

3. Great potential and increasing awareness for floating PV.

4. Availability of water bodies and land issues are main accelerators for floating PV Solar Panels.

5. Increased efficiency of Floating PV over Land PV installed

6. Availability of trained manpower and Govt. Policies have boosted the confidence of investors.

7. Stable floating PV platforms results in minimum operation \& maintenance cost.

8. The emergence of new markets and investments in India, China, Thailand, Malaysia and other developing countries.

\section{Weakness (internal, negative factors)}

1. Long-term maintenance requirements and durability of floating solar PV is yet to be seen.

2. Ecological and adverse impacts on water ecosystem.

3. Relatively young and immature technology.

4. Lack of experience and knowledge.

5. Lack of cooperation from local distribution utility.

6. Solar energy concentration levels on floating platform.

7. high waves and salt water possibly damage the solar panels over time.

\section{Threat (external, negative factors)}

1. Large dependency on land-based PV generation.
2. Lack of testing and standard procedures of floating solar.

3. Untested Technology for long run.

4. No promotion and support through a separate policy.

5. Cost concerns and lack of financial resources.

6. Cumbersome maintenance and repair.

\section{Environmental effects of floating solar}

Floating solar platform allows standard PV panels to be installed on large bodies of water such as drinking water reservoirs, quarry lakes, irrigation canals or remediation and tailing ponds. simple and affordable floating solar platform is particularly well suitable for energy and water-intensive industries who cannot afford to waste either land or water. Wineries, dairy farms, fish farms, mining companies, wastewater treatment plants, irrigation districts and water agencies are industries which can benefit from the synergy that floating solar system creates between sun and water

\section{Conclusion}

Floating solar concept seems simple enough, but there are major technological hurdles. Floating solar application with challenges and opportunities has been discussed.

1. The SWOT analysis presented in this paper can be utilized as tool for future development of floating photovoltaic systems

2. To revolutionize floating solar, threats identified need to be tracked appropriately. However, the future seems bright for the floating solar technology

3. In the near future, the surface of the water bodies associated with hydroelectric dams, pumped storage installations, and cooling ponds of electric power plants-locations that typically have existing power grid connections will be totally covered with the floating system.

4. Floating Solar system is technically feasible and economically viable.

\section{Acknowledgments}

None.

\section{Conflicts of interests}

The authors declare that there is no conflict of interest.

\section{References}

1. Hyder Farhan, Sudhakar K, Rizalman Mamat. Solar PV tree design: A review. Renewable and Sustainable Energy Reviews. 2018;82(2018):1079-1096

2. Kumar NM, Sudhakar K, Samykano M. Techno-economic analysis of 1 MWp grid connected solar PV plant in Malaysia. International Journal of Ambient Energy. 2017;1-26.

3. Sahu AK, Sudhakar K. Effect of UV exposure on bimodal HDPE floats for floating solar application. J Mater Res Technol. 2017.

4. Akshay Suhas Baitule, Sudhakar K. Solar powered green campus: a simulation Study. International Journal of Low-Carbon Technologies. 2017;1-11.

5. Akash Kumar Shukla, Sudhakar K, Prashant Baredar, et al. BIPV in Southeast Asian countries - opportunities and challenges. Renewable Energy Focus. 21;25-32. 
6. Kumar P, ShuklaAK, Sudhakar K, et al. Experimental exergy analysis of water-cooled PV module. International Journal of Exergy. 23(3):197-209.

7. Deepak Bishoyi, Sudhakar K. Experimental Performance of Direct Evaporative cooler in a composite climate of India. Energy and Buildings. 2017;153:190-200.

8. Deepak Bishoyi, Sudhakar K. Modeling and performance simulation of 100MW PTC based solar thermal power plant in Udaipur India. Case Studies in Thermal Engineering. 2017;10:216-226.

9. Deepak Bishoyi, Sudhakar K. Modeling and performance simulation of $100 \mathrm{MW}$ LFR based solar thermal power plant in Udaipur India. Resource-Efficient Technologies. 2017;10:216-226.

10. Sreenath Sukumaran, Sudhakar K. Fully solar powered airport: A case study of Cochin International airport. Journal of Air Transport Management. 2017;62:176-188.

11. Sreenath Sukumaran, Sudhakar K. Fully solar powered Raja Bhoj International Airport: A feasibility study. Resource-Efficient Technologies. 2017.

12. Debbarma M, Sudhakar K. Thermal modeling, exergy analysis, performance of BIPV and BIPVT: a review. Renew Sustain Energy Rev. 2017;73:1276-88.

13. Akash Kumar Shukla, Sudhakar K, Prashant Baredar. Recent advancement in BIPV product technologies: A review. Energy and Buildings. 2017;140.

14. Akash Kumar Shukla, Sudhakar K, Prashant Baredar. Renewable energy resources in South Asian countries: Challenges, policy and recommendations. Resource-Efficient Technologies. $2017 ; 3(3): 342-346$.

15. Mary Debbarma, Sudhakar K, Prashant Baredar. Comparison of BIPV and BIPVT: A review. Resource-Efficient Technologies. 2017;3(3):263-271.

16. Dayal Singh Rajput, Sudhakar K. Effect of Dust On The Performance Of Solar PV Panel. International Journal of Chem Tech Research. 2013.

17. Akash Kumar Shukla, Sudhakar K, Prashant Baredar. Design, simulation and economic analysis of standalone roof top solar PV system in India. Solar Energy. 2016;136:437-449.
18. Akash Kumar Shukla, Sudhakar K, Prashant Baredar. A comprehensive review on design of building integrated photovoltaic system. Energy and Buildings. 2016;128:99-110.

19. Jay Prakash Bijarniya, Sudhakar K, Prashant baredar. Concentrated solar power technology in India: A review. Renewable and Sustainable Energy Reviews. 2016;63:593-603.

20. Akash Kumar Shukla, Sudhakar K, Prashant Baredar. Exergetic analysis of building integrated semitransparent photovoltaic module in clear sky condition at Bhopal India. Case Studies in Thermal Engineering. $2016 ; 8$.

21. Sudhakar K, Prashant Baredar, Akash Kumar Shukla. Simulation and performance analysis of $110 \mathrm{kWp}$ grid-connected photovoltaic system for residential building in India: A comparative analysis of various PV technology. Energy Reports. 2016;2(C):82-88.

22. Akash Kumar Shukla, Sudhakar K, Prashant Baredar. Exergetic assessment of BIPV module using parametric and photonic energy methods: A review. Energy and Buildings. 2016;119:62-73.

23. Shiva Kumar B, Sudhakar K. Performance evaluation of 10 MW gridconnected solar photovoltaic power plant in India. 2015;1(C):184-192.

24. Sudhakar K, Shukla KN, Saroj Rangnekar. A comparative study of exergetic performance of amorphous and polycrystalline solar PV modules. International Journal of Exergy. 2015;17(4):433-455.

25. Vipinraj Sugathan, Elsa John, Sudhakar K. Recent improvements in dye sensitized solar cells: A review. Renewable and Sustainable Energy Reviews. 2015;52.

26. Sudhakar K, Tulika Srivastava. Energy and exergy analysis of $36 \mathrm{~W}$ solar photovoltaic module. International Journal of Ambient Energy. 2014;35(1):51-57.

27. Alok sahu, Neha yadav, Sudhakar K. Floating photo voltaic power plant: A review. Renewable and Sustainable Energy Reviews. 2016;66:815-824.

28. Yadav N, Gupta M, Sudhakar K. Energy assessment of floating photovoltaic system. 2016 International Conference on Electrical Power and Energy Systems (ICEPES), Bhopal; 2016:264-269. 